\title{
PENYELIDIKAN EPIDEMIOLOGI KEJADIAN LUAR BIASA (KLB) KERACUNAN PANGAN DI KAMPUNG CIJOHO RW O1 DESA SIRNAMEKAR KABUPATEN SUKABUMI TAHUN 2019
}

\author{
Yeni Suryamah \\ Kantor Kesehatan Pelabuhan Kelas II Bandung \\ yeni_suryamah@hotmail.com
}

\begin{abstract}
Abstrak
Setiap makanan selalu mengalami proses penyediaan bahan mentah, pengolahan, penyimpanan dan distribusinya sampai di meja makan yang berisiko terjadinya keracunan, baik keracunan karena pangan itu sendiri beracun atau adanya bahan racun yang mencemari makanan. Keracunan pangan sering dikaitkan dengan pengelolaan atau penyimpanan makanan yang tidak atau kurang higienis. Faktor perilaku merupakan hal yang berperan penting dalam berbagai kasus. selain itu faktor lingkungan dengan kondisi sanitasi yang tidak memadai atau kurang memenuhi syarat kesehatan juga berpengaruh dengan berbagai kejadian keracunan pangan. Tujuan penyeldikan epidemiologi ini adalah untuk memperoleh gambaran dan faktor-faktor yang berpengaruh terhadap kejadian KLB Keracunan pangan di Kampung Cijoho RW 01 Desa Sirnamekar Kecamatan Tegalbuled Kabupaten Sukabumi. Desain studi ini menggunakan deskriptif Cohort Historical dengan waktu pengumpulan data dimulai pada Jumat 15 Nopember 2019 hingga 19 Nopember 2019. Populasi penelitian adalah seluruh kasus keracunan makanan di Wilayah Kampung Cijoho RW 01 Desa Sirnamekar Kecamatan Tegalbuled Kabupaten Sukabumi. sedangkan sampel terdiri dari kasus yang memenuhi kriteria kasus dan kontrol yang memenuhi kriteria control yaitu orang yang memakan makanan syukuran namun tidak menjadi sakit. Hasil penyelidikan epidemiologi didapatkan bahwa Attack rate KLB keracunan pangan terbesar pada jenis kelamin perempuan $(0.041 \%)$ dan kelompok umur $15->60$ tahun $(0.029 \%)$. Case Fatality Rate pada KLB Keracunan Pangan sebesar 0.027. Gejala terbanyak pada kejadian KLB keracunan pangan ini adalah gejala mual $77.9 \%$ (60 orang) dan diare $67.5 \%$ (52 orang). Kurva epidemik pada kejadian KLB ini berbentuk common source dengan rentang masa inkubasi 30 menit sampai dengan 79.5 jam, dengan mean inkubasi 12,51 jam. Berdasarkan masa inkubasi diperoleh informasi bahwa agent penyebab penyakit yang memungkinkan adalah bakteri E.colli. Berdasarkan jenis makanan yang dimakan, dicurigai bahwa makanan yang berisiko menyebabkan keracunan adalah bihun, dengan selisih attack rate sebesar 0.12 . Hasil pemeriksaan rapid test pada alat masak didapatkan hasil positif mengandung residu glukosa dan residu protein. Rekomendasi antara lain diperlukan adanya penguatan Program sanitasi lingkungan, Peningkatan kembali sosialisasi dari perangkat daerah yang menangani kesehatan lingkungan serta meningkatkan kembali pola partisipasi masyarakat melalui pemberdayaan masyarakat
\end{abstract}

Kata Kunci : KLB, Keracunan Pangan, Penyelidikan Epidemiologi

\begin{abstract}
Every food always experiences the process of supplying raw materials, processing, storing and distributing it to the dinner table which is at risk of poisoning, either poisoning because the food itself is poisonous or the presence of poisonous substances that pollute food. Food poisoning is often associated with the management or storage of food that is not or less hygienic. Behavioral factors are things that play an important role in various cases. In addition, environmental factors with inadequate sanitation conditions or inadequate health requirements also affect various food poisoning incidents.
\end{abstract}


The purpose of this epidemiological investigation is to obtain an overview and factors that influence the incidence of food poisoning outbreaks in Cijoho Village RW 01 Sirnamekar Village, Tegalbuled District, Sukabumi Regency. The study design uses descriptive Historical Cohort with data collection time starting on Friday 15 November 2019 until 19 November 2019. The study population was all cases of food poisoning in the Cijoho Village RW 01 Sirnamekar Village Tegalbuled District Sukabumi District. while the sample consists of cases that meet the criteria of cases and controls that meet the control criteria, namely people who eat thanksgiving food but do not become ill. The results of epidemiological investigations found that the outbreak of food poisoning outbreaks was greatest in the female sex $(0.041 \%)$ and the age group 15-> 60 years $(0.029 \%)$. Case Fatality Rate in KLB Food Poisoning is 0.027. The most common symptom in the outbreak of food poisoning was nausea of $77.9 \%$ (60 people) and diarrhea $67.5 \%$ (52 people). The epidemic curve in the outbreak event is in the form of a common source with an incubation period of 30 minutes to 79.5 hours, with a mean incubation of 12.51 hours. Based on the incubation period, information was obtained that the possible causative agent was E. coli bacteria. Based on the type of food eaten, it is suspected that food that is at risk of causing poisoning is vermicelli, with a difference in attack rate of 0.12 . The results of the rapid test on the cookware showed positive results containing glucose residues and protein residues. Recommendations include the need to strengthen the environmental sanitation program, re-increase the socialization of the regional apparatus that handles environmental health and to increase the pattern of community participation through community empowerment.

Keywords : Outbreaks, Food Poisoning, Epidemiological Investigations

\section{PENDAHULUAN}

Setiap makanan selalu mengalami proses penyediaan bahan mentah, pengolahan, penyimpanan dan distribusinya sampai di meja makan di setiap rumah tangga, pertemuanpertemuan, pesta, makanan jajanan, restauran dan berbagai cara distribusi pangan. Semuanya mempunyai risiko terjadinya keracunan, baik keracunan karena pangan itu sendiri beracun atau adanya bahan racun yang mencemari makanan (Imari, 2011: 4)

Keracunan pangan sering dikaitkan dengan pengelolaan atau penyimpanan makanan yang tidak atau kurang higienis. Faktor perilaku merupakan hal yang berperan penting dalam berbagai kasus. selain itu faktor lingkungan dengan kondisi sanitasi yang tidak memadai atau kurang memenuhi syarat kesehatan juga berpengaruh dengan berbagai kejadian keracunan pangan. Kejadian keracunan makanan biasanya disebabkan karena mengkonsumsi makanan dan minuman yang telah terkontaminasi dengan bakteri, parasit atau virus dan bahan kimia berbahaya (Bekti, 2011).

Kejadian Luar Biasa (KLB) Keracunan Pangan adalah adanya dua orang atau lebih yang menderita sakit dengan gejala yang sama atau hampir sama setelah mengkonsumsi pangan, dan berdasarkan analisis epidemiologi, pangan tersebut terbukti sebagai sumber penularan (PP no 28 tahun 2004 tentang Keamanan, Mutu dan Gizi Pangan, penjelasan pasal 25 ayat 3 ).

KLB keracunan pangan masih menjadi masalah kesehatan ditingkat nasional maupun regional. Hal ini disebabkan semakin meningkatnya industri pangan masak maupun bahan mentah dan pola pengawasannya yang belum jelas.

Mencermati besarnya masalah kejadian keracunan, khususnya keracunan pangan maka 
sangat diperlukan kemampuan bertindak cepat dan tepat serta kemampuan menghimpun data epidemiologi untuk menentukan arah penguatan kapasitas program dan identifikasi daerah atau populasi tertentu yang lebih spesifik, terutama kemampuan melakukan investigasi kejadian keracunan pangan (Imari, 2011:6).

Pada hari Jumat, tanggal 15 November 2019, Dinas Kesehatan Kabupaten Sukabumi menerima laporan KLB dari Puskesmas Bangbayang yang di duga akibat keracunan pangan. Berdasarkan laporan awal tersebut sebanyak 77 penderita diobat di sarana pelayanan puskesmas dengan gejala mual, muntah, pusing, diare, demam, panas tenggorokan dan panas perut. Selanjutnya atas dasar informasi tersebut Dinas Kesehatan Kabupaten Sukabumi berkoordinasi dengan Kantor Kesehatan Pelabuhan Kelas II Bandung wilker Palabuhan Ratu untuk melakukan investigasi ke lokasi kejadian.

Adapun tujuan dari penyelidikan epidemiologi ini adalah untuk Memperoleh gambaran dan faktor-faktor yang berpengaruh terhadap kejadian KLB Keracunan pangan di Kampung Cijoho RW 01 Desa Sirnamekar Kecamatan Tegalbuled Kabupaten Sukabumi dengan focus kepada :

1) Memastikan adanya KLB keracunan pangan

2) Mengetahui distribusi kasus berdasarkan variabel tempat

3) Mengetahui distribusi kasus KLB berdasarkan variabel orang
4) Mengetahui distribusi kasus KLB berdasarkan variabel waktu.

5) Mengetahui faktor risiko KLB Keracunan pangan

6) Mengetahui deskripsi pengolahan pangan yang diduga menjadi sumber KLB

7) Mengetahui sumber penularan

8) Mengetahui attcak rate dan case fatality rate pada KLB keracunan pangan

9) Mengetahui kurve epidemik KLB keracunan pangan

Kejadian Luar Biasa (KLB) Keracunan Pangan adalah adanya dua orang atau lebih yang menderita sakit dengan gejala yang sama atau hampir sama setelah mengkonsumsi pangan, dan berdasarkan analsis epidemiologi, pangan tersebut terbukti sebagai sumber penularan (PP 28 , 2004 tentang Keamanan, Mutu dan Gizi Pangan, penjelasan pasal 25 ayat 3).

Makanan yang terkontaminasi dapat menimbulkan gejala penyakit baik infeksi maupun keracunan. Kontaminasi makanan adalah terdapatnya bahan atau organisme berbahaya dalam makanan secara tidak sengaja. Bahan atau organisme berbahaya disebut kontaminan.

Gejala dan tanda-tanda klinik keracunan pangan sangat bergantung pada jenis etiologinya, tetapi secara umum gejala keracunan pangan dapat digolongkan ke dalam 6 kelompok yaitu :

1. Gejala utama yang terjadi pertama-tama pada saluran gastrointestinal atas (mual, muntah).

2. Gejala sakit tenggorokan dan pernafasan. 
3. Gejala utama terjadi pada saluran gastrointestinal bawah (kejang perut, diare).

4. Gejala neurologik (gangguan penglihatan, perasaan melayang, paralysis).

5. Gejala infeksi umum (demam, menggigil, rasa tidak enak, letih, pembengkakan kelenjar limfe).

6. Gejala alergik (wajah memerah, gatal-gatal).

Secara umum etiologi keracunan pangan disebabkan oleh jenis kuma bakteri, virus, parasit, jamur dan jenis kimiawi.

a. Jenis kuman dapat kumannya beracun, atau kuam yang memproduksi racun. Kuman dapat berkembang biak dalam pangan kemudian menimbukan keracunan pangan, atau masuk dalam tubuh korban kemudian berkembang biak dan terjadi keracunan pangan.

b. Jenis kimia dapat berasal dari pertumbuhan kuman yang memproduksi racun, atau adanya bahan racun organik maupun unorganik yang mencemari pangan. Sering kali pangan sendiri sebagai bahan racun.

Bahan beracun memiliki sifat-sifat khusus, ketersediannya dialam, distribusinya, gejala sakit, masa inkubasi, fatalitas korban keracunan, keberadaan pada makanan. Beberapa jenis virus dan bakteri terdapat secara umum di lingkungan sekitar dan bahkan seringkali menimbulkan pencemaran pada makanan tertentu. Ahli keracunan yang bekerja di laboratorium, sering kali memulai penyelidikan keracunan pangan, justru drai jenis virus/bakteri yang sering terdapat pada jenis makanan tertentu (Imari, 2011:32)

\section{METODE PENELITIAN}

Desain studi ini menggunakan deskriptif Cohort Historical dengan batasan waktu KLB keracunan Pangan pada Jumat 15 Nopember 2019 hingga 19 Nopember 2019 yang berada di Kampung Cijoho RW 01 Desa Sirnamekar Kecamatan Tegalbuled Kabupaten Sukabumi. Sementara Definisi Operasional Kasus adalah Orang yang didiagnosa oleh dokter Puskesmas atau Rumah Sakit setempat sebagai kasus KLB. Populasi penelitian adalah seluruh kasus keracunan makanan di Wilayah Kampung Cijoho RW 01 Desa Sirnamekar Kecamatan Tegalbuled Kabupaten Sukabumi. sedangkan sampel terdiri dari kasus yang memenuhi kriteria kasus dan kontrol yang memenuhi kriteria control yaitu orang yang memakan makanan syukuran namun tidak menjadi sakit. Pengumpulan data untuk penyelidikan epidemiologi dilakukan dengan cara:

1. Pengumpulan data sekunder yang terdapat di Dinas Kesehatan Kabupaten, puskesmas lokasi KLB Keracunan Pangan yaitu: Jumlah Penduduk Desa lokasi KLB, Usia kasus, Alamat kasus, Profil Desa,Penyedia Jasa Pangan, Jenis pangan/menu yang dikonsumsi, Kondisi Lingkungan, Hasil laboratorium sampel pangan dan lingkungan, Upaya penanggulangan yang telah dilakukan.

2. Pengumpulan data primer dengan menggunakan instrumen kuesioner yang ditanyakan kepada kasus dan kontrol KLB Keracunan Pangan

Proses pengolahan data analisis situasi ini meliputi tahapan sebagai berikut, yaitu: 
1. Perangkat lunak untuk pengolahan data yang diperoleh diolah secara komputerisasi menggunakan program Microsoft Office

2. Analisis data sekunder dan primer berupa : Data jumlah penderita menurut kelompok umur, Curve epidemik Keracunan Pangan, Distribusi kasus KLB Keracunan Pangan,Menganalisis distribusi kasus KLB Keracunan Pangan berdasarkan variabel, orang, tempat dan waktu, attack rate dan case fatality rate, Mendeskripsikan upaya yang telah dilakukan untuk menanggulangi KLB Keracunan Pangan yang telah terjadi

\section{HASIL DAN PEMBAHASAN}

\section{Deskripsi Wilayah Desa Sirnamekar}

Desa Sirnamekar merupakan salahsatu di Kecamatan Tegalbuleud yang memiliki luas wilayah 1.750 ha dan terbagi menjadi 4 Kedusunan dan 12 ke-RT-an. Dengan BatasBatas Desa sebagai berikut

- Sebelah utara berbatasan dengan Sungai Cikaso, Desa Bojong Kecamatan Kalibunder.

- Sebelah selatan berbatasan dengan Desa Nangela Kecamatan Tegalbuleud

- Sebelah timur berbatasan dengan Desa Bangbayang Kecamatan Tegalbuleud

- Sebelah barat berbatasan dengan Desa Cimahpar Kecamatan Kalibunder

Orbitasi Desa

- Jarak ke Ibu Kota Kecamatan :78 Km

- Lama jarak tempuh ke Ibu Kecamatan : 3 Jam
- Jarak ke Ibu Kota Kabupaten : 120 Km

- Lama jarak tempuh ke Ibu Kabupaten : 4 Jam

- Jarak ke Ibu Kota Propinsi : 230 Km

- Lama jarak tempuh ke Ibu Propinsi : 7 Jam

\section{Kronologis Kejadian}

Pada hari Jumat, tanggal 15 November 2019, BP.Pudin Di Kp Cijoho Rt 01 Rw 01 Desa Sirnamekar Kec. Tegalbuleud, Kab. Sukabumi menggelar acara Syukuran Tahfidz Qur'an. Acara tersebut dilaksanakan selama satu hari, yaitu Hari Jumat (Syukuran). Untuk acara hari Jumat makanan mulai siap disajikan sejak pukul $16.00 \mathrm{wib}$,

Ada beberapa makanan yang dihidangkan dalam acara syukuran Tahfidz Qur'an : antara lain Daging Ayam Bumbu, Bihun, nasi putih, Bugis, papais, ulen. Makanan disajikan dengan dibungkus dan ketika hendak pulang, masingmasing keluarga dibekali dengan 1 dus makanan dengan menu yang sama yang di kemas dalam nasi bok putih berbungkus steyrofoam.

Pada hari Sabtu siang, tanggal 16 November 2019, sekitar pukul 14.00WIB sampai dengan sabtu pagi ada beberapa warga mengeluh mual, muntah-muntah disertai pusing setelah menyantap hidangan dari acara syukuran tersebut. Kemudian warga yang mengeluh gejala yang sama semakin bertambah di sekitar jam 12.00WIB hingga jam 19.00WIB. Selanjutnya Ketua RT melapor Ke Kepala Dusun Cijoho (enyang) pada jam 19.00WIB dan menginformasikan ke Bidan 
Desa dan Kepala Puskesmas Bangbayang. Selanjutnya bidan Desa Sirnamekar memutuskan untuk membawa korban ke pustu terdekat (pustu Sirnamekar) dan meminta bantuan Puskesmas Bangbayang untuk bantuan medis dan membuka Posko Kesehatan. Hingga hari Minggu tanggal 17 November pada pukul 07.00WIB sampai dengan pukul 16.00WIB, total kasus yang tercatat bertambah sejumlah 77 orang. Pada pukul 11.00 mendapatkan kabar melalui telepon 1 orang dinyatakan meninggal dunia atas nama Holis berumur 55 tahun yang bertempat di kp Cikupa Desa Sirnamekar Kecamatan Tegalbuleud. Minggu Jam 14.00 ada 2 Orang yang dirujuk ke RSUD Jampangkulon. Senin jam 07.00 mendapatkan kabar 1 orang meninggal dunia atas nama yoyoh 54 tahun yang bertempat di kp.Cijoho.

\section{Deskripsi Pengolahan Pangan Yang Diduga Menjadi Sumber Penyebab \\ a. Profil Pengolah Pangan}

Pengelolaan pangan di tingkat desa untuk acara khusus/hajatan di lingkungan masyarakat masih menggunakan tenaga pengolah setempat yang belum terlatih dan menerapkan sistem kekeluargaan yang tradisonal. Tenaga pengolah makanan belum menerapkan sistem keamanan pangan karena masih tradisonal dan lokasi kejadian merupakan daerah pedesaan yang belum memiliki kelompok pengusaha catering.

\section{b. Bahan dan Alat}

Bahan makanan yang digunakan merupakan bahan makanan setempat, dalam pengelolaannya belum memperhatikan karakteristik dari makanan tersebut, masa kalaluarsa, cara perlakuan terhadap bahan dan alat masih tradisional. Alat yang digunakan masih menggunakan alat masak standar, bahkan dapurnya masih menggunakan tungku sederhana dan masih beralaskan tanah. Selain itu kulaitas air yang digunakan dalam pengoalah alat dan bahan makanan masih menggunakan sumber air dari mata air dan air permukaan, dan belum pernah dilakukan pemeriksaan sampel air.

\section{c. Proses Pengolahan}

Tabel 1 Proses Pengolahan Pangan yang diduga menjadi Sumber Penyebab KLB

\begin{tabular}{|c|c|c|c|c|}
\hline \multirow[b]{2}{*}{ No } & \multicolumn{2}{|c|}{ Waktu } & \multirow[b]{2}{*}{ Uraian } & \multirow[b]{2}{*}{ Keterangan } \\
\hline & Tanggal & $\begin{array}{c}\text { Jam } \\
\text { (WIB) }\end{array}$ & & \\
\hline 1 & $\begin{array}{c}\text { Kamis, } \\
14 \text { Nov. } \\
2019\end{array}$ & 22.00 & $\begin{array}{l}\text { Pembuatan } \\
\text { bahan ulen } \\
\text { ketan kemudian } \\
\text { diangin } \\
\text { anginkan di } \\
\text { dalam rumah }\end{array}$ & $\begin{array}{l}\text { Koki } \\
\text { tersebut an. } \\
\text { Ibu Holis } \\
\text { yang } \\
\text { kemudian } \\
\text { meninggal }\end{array}$ \\
\hline \multirow[t]{2}{*}{2} & $\begin{array}{c}\text { Jumat, } \\
15 \\
\text { Nopembe } \\
\text { r } 2019\end{array}$ & 06.00 & $\begin{array}{l}\text { Bahan makanan } \\
\text { di beli di } \\
\text { warung Haryadi } \\
\text { oleh yang punya } \\
\text { hajat (bpk. } \\
\text { Pidin) }\end{array}$ & $\begin{array}{l}\text { sabtu } 16 \\
\text { nopember. } \\
\text { Saat akan } \\
\text { memasak } \\
\text { ibu Holis } \\
\text { sebenarnya }\end{array}$ \\
\hline & & 07.00 & $\begin{array}{l}\text { Bahan makanan } \\
\text { tersebut di olah } \\
\text { oleh Kolmak } \\
\text { (koki masak) } \\
\text { dan } 5 \text { orang } \\
\text { lainnya dari } \\
\text { mulai meracik } \\
\text { bumbu hingga } \\
\text { pemotongan } \\
\text { ayam. Sisa } \\
\text { bumbu di } \\
\text { simpan di } \\
\text { kulkas. } \\
\text { keperluan air } \\
\text { bersih untuk } \\
\text { memasak } \\
\text { diambil dari } 2 \\
\text { sumber mata air } \\
\text { yang keduanya } \\
\text { merupakan mata }\end{array}$ & $\begin{array}{l}\text { sudah } \\
\text { mengeluh } \\
\text { sakit dan } \\
\text { sudah } \\
\text { berobat ke } \\
\text { puskesmas } \\
\text { namun tetap } \\
\text { memaksaka } \\
\text { n diri untuk } \\
\text { memasak }\end{array}$ \\
\hline
\end{tabular}




\begin{tabular}{|c|c|}
\hline & $\begin{array}{l}\text { air yang tidak } \\
\text { terawat, dengan } \\
\text { menggunakan } \\
\text { jeligen milk pak } \\
\text { pudin } 2 \text { buah } \\
\text { dan milik bu } \\
\text { olis } 2 \text { buah. }\end{array}$ \\
\hline 14.00 & $\begin{array}{l}\text { Masakan selesai } \\
\text { dimasak } \\
\text { kemudian } \\
\text { dikemas. } \\
\text { Kemasan nasi } \\
\text { menggunakan } \\
\text { daun pisang, } \\
\text { bihun dan } \\
\text { daging } \\
\text { dimasukan ke } \\
\text { dalam satu } \\
\text { plastic. Ulen } \\
\text { ketan dan bugis } \\
\text { juga disatukan } \\
\text { ke dalam satu } \\
\text { plastic. } \\
\text { Makanan yang } \\
\text { di bungkus } \\
\text { dibuat sebanyak } \\
40 \text { dus. }\end{array}$ \\
\hline 16.00 & Acara dimulai. \\
\hline
\end{tabular}

\section{d. Distribusi Makanan}

Orang yang datang berkunjung disuguhkan makanan secara prasmanan. Tapi jika ada undangan/kerabat yang tidak hadir, maka makanan tersebut (makanan dalam dus) diantarkan ke rumahnya. Sebanyak 40 dus diantarkan kepada tetangga/kerabat yang tidak bias hadir saat itu.

\section{Deskripsi Kejadian Luar Biasa Keracunan Pangan}

a. Deskripsi Kasus Berdasarkan Tempat Tabel 2 Validasi Data Kasus KLB Keracunan Pangan Di Kampung Cijoho Desa Sirnamekar Kecamatan Tegalbuleud Kab. Sukabumi 15-19 Nopember 2019

\begin{tabular}{|c|c|c|c|c|}
\hline No & $\begin{array}{c}\text { Sumber } \\
\text { Data }\end{array}$ & $\begin{array}{c}\text { Jumlah } \\
\text { Tercatat }\end{array}$ & $\begin{array}{c}\text { Hasil } \\
\text { Validasi }\end{array}$ & Keterangan \\
\hline 1 & $\begin{array}{l}\text { Puskesma } \\
\text { s } \\
\text { Bangbaya } \\
\text { ng }\end{array}$ & 77 pasien & $\begin{array}{l}77 \\
\text { pasien }\end{array}$ & $\begin{array}{l}\text { Pasien yang } \\
\text { datang ke } \\
\text { posko KLB di } \\
\text { kampung } \\
\text { Cijoho }\end{array}$ \\
\hline
\end{tabular}

\begin{tabular}{|c|c|c|c|c|}
\hline 2 & $\begin{array}{l}\text { RSUD } \\
\text { Jampang } \\
\text { Kulon }\end{array}$ & 6 Pasien & 6 pasien & $\begin{array}{l}\text { Adalah pasien } \\
\text { KLB } \\
\text { keracunan } \\
\text { pangan } \\
\text { kampong } \\
\text { cijoho yang } \\
\text { dirujuk ke RS } \\
\text { Jampang } \\
\text { Kulon tgl 15- } \\
\text { 19Nopember } \\
\text { 2019. } \\
\text { Dari } 6 \text { pasien } \\
\text { tersebut } \\
\text { sebanyak } 2 \\
\text { orang } \\
\text { meninggal } \\
\text { yaitu : an ibu } \\
\text { Holis 55 tahun } \\
\text { (meninggal } 16 \\
\text { Nopember } \\
\text { 2019) dan Ibu } \\
\text { yoyoh } 54 \\
\text { tahun } \\
\text { (meninggal } \\
\text { 17Nopember } \\
\text { 2019) }\end{array}$ \\
\hline 3 & $\begin{array}{l}\text { Kuesioner } \\
\text { KKP } \\
\text { Kelas II } \\
\text { Bandung }\end{array}$ & 84 & 84 & $\begin{array}{l}\text { Bersama tim } \\
\text { Dinkes Kab } \\
\text { Sukabumi, } \\
\text { Puskesmas } \\
\text { Bangbayang, } \\
\text { HAKLI Kab. } \\
\text { Sukabumi dan } \\
\text { PAEI Jabar }\end{array}$ \\
\hline & al Kasus & & 76 kasus & \\
\hline
\end{tabular}

Peta 1 Sebaran Kasus KLB Keracunan Pangan Di Kampung Cijoho Desa Sirnamekar Kecamatan Tegalbuleud Kab. Sukabumi 15-19 Nopember 2019

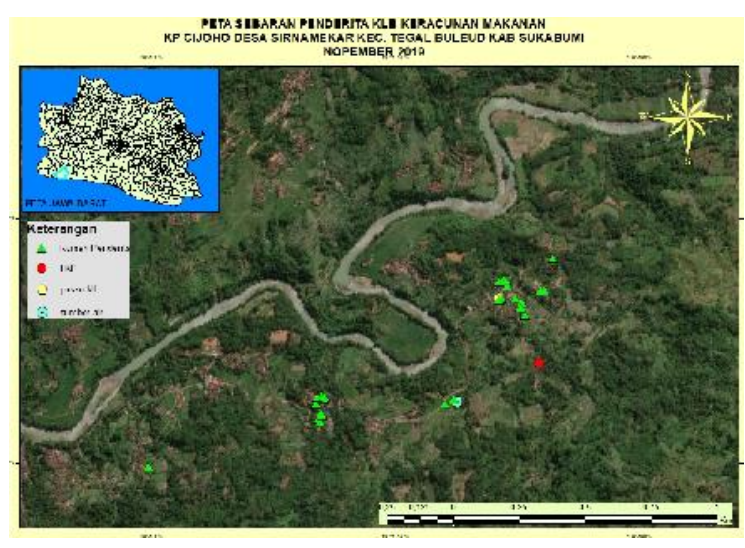

Tabel 3 Prosentase Kasus Berdasarkan Domisili Pada Kejadian KLB Keracunan Pangan Di Kampung Cijoho Desa Sirnamekar Kecamatan Tegalbuleud Kab. Sukabumi 15-19 Nopember 2019 


\begin{tabular}{|c|c|c|c|c|c|}
\hline \multirow{3}{*}{ No } & \multirow{3}{*}{$\begin{array}{c}\text { Domisili } \\
\text { (RT/RW) }\end{array}$} & \multirow{2}{*}{\multicolumn{2}{|c|}{ Jumlah Kasus }} & \multirow{3}{*}{$\begin{array}{c}\% \\
\text { kasus }\end{array}$} & \multirow{3}{*}{$\frac{\text { Wanita }}{\text { Jumlah }}$} \\
\hline & & & & & \\
\hline & & sakit & meninggal & & \\
\hline 1 & $01 / 01$ & 45 & 0 & 60.00 & 0 \\
\hline \multirow[t]{2}{*}{2} & $03 / 01$ & 30 & 2 & 40.00 & 0.067 \\
\hline & Jumlah & 75 & 2 & 100.00 & 0.027 \\
\hline
\end{tabular}

Berdasarkan domisili diketahui Bahwa penderita tinggal di dua RT yaitu RT 01 dan RW 03. Proporsi penderita yang berdomisili di RT 01/01 sebesar 60\% dan Proporsi penderita di RT.03 sebesar $40 \%$ dengan CFR sebesar 0.067 .

\section{b. Deskripsi Kasus Berdasarkan Orang}

Tabel 4 Prosentase Kasus Berdasarkan Kelompok Umur Pada Kejadian KLB Keracunan Pangan Di Kampung Cijoho Desa Sirnamekar Kecamatan Tegalbuleud Kab. Sukabumi 15-19 Nopember 2019

\begin{tabular}{llrrrrr}
\hline No & $\begin{array}{c}\text { Kelompok } \\
\text { Umur }\end{array}$ & \multicolumn{2}{c}{ Jumlah Kasus } & \multicolumn{2}{c}{$\begin{array}{r}\% \\
\text { kasus }\end{array}$} & CFR \\
\cline { 3 - 6 } 1 & $<1$ th & 0 & 0 & 0 & 0 \\
\hline 2 & $1-4$ th & 1 & 0 & 1.33 & 0 \\
\hline 3 & $5-14$ th & 4 & 0 & 5.33 & 0 \\
\hline 4 & $15-60>$ th & 70 & 2 & 93.33 & 0.029 \\
\hline & Jumlah & 75 & 2 & 100.00 & 0.027 \\
\hline
\end{tabular}

Proporsi KLB Keracunan Pangan pada kelompok usia 1-4 tahun sebesar 1.33\%, kelompok 5-14 tahun sebesar 5.33\% dan 1560tahun sebesar $93.33 \%$ dengan kasus meninggal sebanyak 2 orang $(\mathrm{CFR}=0.027)$

Tabel 5 Prosentase Kasus Berdasarkan Jenis Kelamin Pada Kejadian KLB Keracunan Pangan Di Kampung Cijoho Desa Sirnamekar Kecamatan Tegalbuleud Kab. Sukabumi 15-19 Nopember 2019

\begin{tabular}{lrrrrrrr}
\hline \multirow{2}{*}{$\begin{array}{c}\text { Jenis } \\
\text { Kelamin }\end{array}$} & \multirow{2}{*}{$\begin{array}{c}\text { Population } \\
\text { at risk }\end{array}$} & \multicolumn{2}{c}{ Jumlah Kasus } & \multirow{2}{*}{\begin{tabular}{l} 
\% \\
\cline { 3 - 5 } kasus
\end{tabular}} & AR & CFR \\
\hline Pria & 1110 & 32 & & 0 & 42.67 & 0.029 & 0 \\
\hline
\end{tabular}




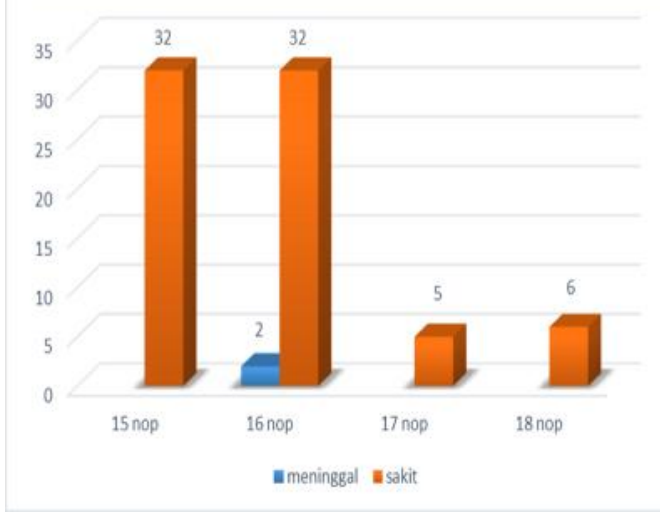

Berdasarkan waktu diketahui jumlah penderita yang tercatat berada pada tanggal 15 nopember dan 16 nopember yaitu sebanyak 32 penderita. Sementara pada tanggal 17 nopember turun drastis menjadi 5 penderita dan 18 nopember sebanyak 6 penderita.

\section{d. Deskripsi Kasus Berdasarkan Etiologi Penyakit}

Grafik 2 Distribusi Gejala Penyakit Pada Kejadian KLB Keracunan Pangan Di Kampung Cijoho Desa Sirnamekar Kecamatan Tegalbuleud Kab. Sukabumi 15-19 Nopember 2019

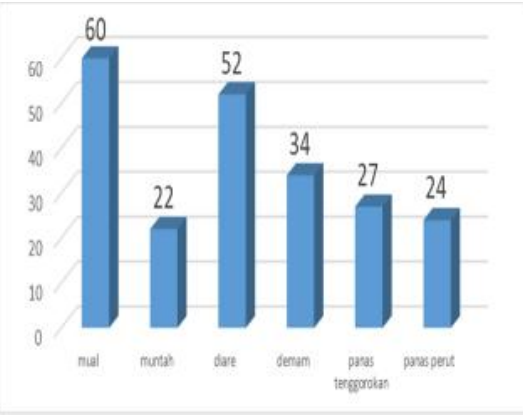

Berdasarkan grafik diatas dapat diketahui bahwa gejala yang paling banyak dialami penderita adalah mual (60 orang), diare (52 orang) dan demam (34 orang) sementara gejala muntah hanya sebanyak 22 orang.

Grafik 3 Distribusi Masa Inkubasi Penyakit Pada Kejadian KLB Keracunan Pangan Di Kampung Cijoho Desa Sirnamekar Kecamatan Tegalbuleud Kab. Sukabumi 15-19 Nopember 2019

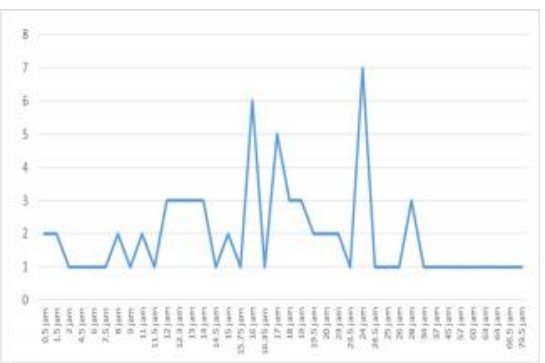

Berdasarkan hasil wawancara, diperoleh informasi bahwa masa inkubasi terpendek adalah 30 menit dan masa inkubasi terpanjang 79.5 jam, dengan jumlah penderita terbanyak ada di masa inkubasi 24 jam (sebanyak 7 orang) dan 16 jam (sebanyak 6 orang). Ratarata masa inkubasi $12.51 \mathrm{jam}$.

Tabel. 7 Dugaan Agen Biologi Penyebab Penyakit dengan Masa Inkubasi Terpendek Pada Kejadian KLB Keracunan Pangan Di Kampung Cijoho Desa Sirnamekar Kecamatan Tegalbuleud Kab. Sukabumi 15-19 Nopember 2019

\begin{tabular}{clccc}
\hline No & $\begin{array}{c}\text { Nama Agent } \\
\text { Penyebab }\end{array}$ & $\begin{array}{c}\text { Masa } \\
\text { Inkubasi } \\
\text { Terpendek }\end{array}$ & $\begin{array}{c}\text { Masa } \\
\text { Inkubasi } \\
\text { Terpendek } \\
\text { Kasus }\end{array}$ & $\begin{array}{c}\text { Agent } \\
\text { Penyakit } \\
\text { Disingkirkan }\end{array}$ \\
\hline 1 & $\begin{array}{l}\text { Staphylococcus } \\
\text { aureus }\end{array}$ & 1 jam & 30 menit & Belum \\
\hline 2 & E. coli & 5 jam & Belum \\
\hline 3 & $\begin{array}{l}\text { V. } \\
\text { parahaemoliticus }\end{array}$ & 2 jam & Belum \\
\hline 4 & V. cholerae & 12 jam & Belum \\
\hline 5 & Bacillus cereus & 30 menit & Belum \\
\hline 6 & Salmonella & 6 jam & Belum \\
\hline
\end{tabular}

Berdasarkan masa inkubasi terpendek yaitu 30 menit maka diagnosis banding KLB yang masih mungkin adalah Staphylococcus aureus, E. coli, V. parahaemoliticus, V.cholerae,Bacillus cereus dan salmonella.

Tabel. 8 Dugaan Agen Biologi Penyebab Penyakit dengan Rata Rata Masa Inkubasi Pada Kejadian KLB Keracunan Pangan Di Kampung Cijoho Desa Sirnamekar Kecamatan Tegalbuleud Kab. Sukabumi 15-19 Nopember 2019 


\begin{tabular}{|c|c|c|c|c|c|c|c|c|c|c|c|}
\hline No & $\begin{array}{c}\text { Nama Agent } \\
\text { Penyebab }\end{array}$ & $\begin{array}{l}\text { Rata- } \\
\text { rata } \\
\text { Masa } \\
\text { Inkubasi }\end{array}$ & \multirow{2}{*}{$\begin{array}{c}\begin{array}{c}\text { Rata- } \\
\text { rata } \\
\text { Masa }\end{array} \\
\text { Inkubasi } \\
\text { Kasus }\end{array}$} & $\begin{array}{c}\text { Agent } \\
\text { Penyakit } \\
\text { Disingkirkan }\end{array}$ & \multicolumn{7}{|c|}{$\begin{array}{l}\text { Pangan Di Kampung Cijoho Desa Sirnamekar } \\
\text { Kecamatan Tegalbuleud Kab. Sukabumi 15-19 } \\
\text { Nopember } 2019\end{array}$} \\
\hline 1 & $\begin{array}{l}\text { Staphylococcus } \\
\text { aureus }\end{array}$ & 2-4 jam & & & \multicolumn{2}{|c|}{ Makan } & \multirow{2}{*}{$\mathbf{A} \mathbf{R}_{\mathbf{M}}$} & \multicolumn{2}{|c|}{ Tidak Makan } & \multirow{2}{*}{$\mathbf{A} \mathbf{R}_{\mathbf{T M}}$} & \multirow{2}{*}{ Selisih } \\
\hline 2 & E. coli & $\begin{array}{l}10-24 \\
\text { jam }\end{array}$ & & Belum & Sakit & $\begin{array}{l}\text { Tidak } \\
\text { sakit }\end{array}$ & & Sakit & $\begin{array}{l}\text { Tidak } \\
\text { Sakit } \\
\end{array}$ & & \\
\hline 3 & $\begin{array}{l}V . \\
\text { parahaemoliticus }\end{array}$ & $12 \mathrm{jam}$ & & Disingksirkan & 25 & 3 & 0.89 & 51 & 4 & 0.93 & 0.03 \\
\hline 4 & $\begin{array}{l}\text { Bacillus cereus } \\
\text { (enteritis) }\end{array}$ & $\begin{array}{l}8-16 \\
\text { jam }\end{array}$ & & BeluBihun & 56 & 3 & 0.95 & 20 & 4 & 0.83 & 0.12 \\
\hline \multirow{4}{*}{\multicolumn{4}{|c|}{$\begin{array}{l}\text { Berdasarkan rata-rata masa inkubasi, } \\
\text { agent penyebab penyakit yang memung } \\
\text { adalah } E \text {. Coli dan Bacillus Cereus. } \\
\text { Bila dilihat dari dugaan penvebab }\end{array}$}} & $\begin{array}{l}\text { Daging } \\
\text { Ayam }\end{array}$ & 61 & 5 & 0.92 & 15 & 2 & 0.88 & 0.04 \\
\hline & & & & & 33 & 5 & 0.87 & 43 & 2 & 0.96 & 0.09 \\
\hline & & & & $\begin{array}{l}\text { gkinkan } \\
\text { Uli Ketan }\end{array}$ & 18 & 1 & 0.95 & 58 & 6 & 0.91 & 0.04 \\
\hline & & & & Papais & 33 & 4 & 0.89 & 43 & 3 & 0.93 & 0.04 \\
\hline
\end{tabular}

Kimiawi dengan rata rata masa inkubasi, memungkinkan untuk terjadinya keracunan timbal. Seperti terlihat pada tabel berikut.

Tabel. 9 Dugaan Agen Kimia Penyebab Penyakit dengan Masa Inkubasi Terpendek Pada Kejadian KLB Keracunan Pangan Di Kampung Cijoho Desa Sirnamekar Kecamatan Tegalbuleud Kab. Sukabumi 15-19 Nopember 2019

\begin{tabular}{|c|c|c|c|c|}
\hline No & $\begin{array}{c}\text { Nama } \\
\text { Agent } \\
\text { Penyebab }\end{array}$ & $\begin{array}{c}\text { Rata-rata } \\
\text { Masa } \\
\text { Inkubasi }\end{array}$ & $\begin{array}{c}\text { Rata-rata } \\
\text { Masa } \\
\text { Inkubasi } \\
\text { Kasus } \\
\end{array}$ & $\begin{array}{c}\text { Agent } \\
\text { Penyakit } \\
\text { Disingkirkan }\end{array}$ \\
\hline 1 & $\begin{array}{l}\text { keracunan } \\
\text { kadmium }\end{array}$ & $\begin{array}{l}\text { beberapa } \\
\text { menit } \\
\text { sampai } \\
\text { beberapa } \\
\text { jam }\end{array}$ & \multirow{5}{*}{$12.51 \mathrm{jam}$} & Disingkirkan \\
\hline 2 & $\begin{array}{l}\text { keracunan } \\
\text { florida }\end{array}$ & $\begin{array}{l}\text { beberapa } \\
\text { menit } \\
\text { sampai } 2 \\
\text { jam }\end{array}$ & & Disingkirkan \\
\hline 3 & $\begin{array}{l}\text { keracunan } \\
\text { timbal }\end{array}$ & $\begin{array}{l}30 \text { menit } \\
\text { atau lebih } \\
\text { lama }\end{array}$ & & Belum \\
\hline 4 & $\begin{array}{l}\text { keracunan } \\
\text { timah }\end{array}$ & $\begin{array}{l}30 \text { menit } \\
\text { sampai } 2 \\
\text { jam }\end{array}$ & & Disingkirkan \\
\hline 5 & $\begin{array}{l}\text { Keracunan } \\
\text { sianida }\end{array}$ & $\begin{array}{l}\text { Beberapa } \\
\text { detik sampai } \\
\text { beberapa } \\
\text { menit }\end{array}$ & & Disingkirkan \\
\hline 6 & $\begin{array}{l}\text { Keracunan } \\
\text { arsenik }\end{array}$ & \pm 1 jam & & Disingkirkan \\
\hline
\end{tabular}

Tabel 10 Attack Rate Makanan yang di Konsumsi Pada Kejadian KLB Keracunan
Bila dilihat dari makanan yang di konsumsi, sebagian besar penderita mengkonsumsi daging ayam (61 orang), dan bihun (56 orang) dan orang yang tidak makan daging ayam namun sakit sebanyak 15 orang. Hal ini tidak jauh berbeda dengan orang yang tidak makan bihun namun sakit (20 orang). Namun bila dilihat dari selisih attack rate terbesar ternyata di duga penyebab keracunan berasal dari makanan bihun $($ selisih attact rate $=0.12)$

\section{Faktor Risiko Yang Memungkinkan}

a. Hasil Wawancara dengan penjamah makanan

Penjamah Makanan Hanya Anggota Keluarga Yang Berjumlah 2 Orang, ditambah ibu Holis dan isap. Bapak. Pudin menyatakan bahwa mereka sudah biasa menyelenggarakan syukuran seperti itu beberapa kali dan tidak ada kejadian apapun.

\section{b. Hasil investigasi lingkungan}

Berdasarkan investigasi ke rumah penyelenggara syukuran (Bpk. Pudin) 


\section{JURNAL SEHAT MASADA VOLUME XIV}

diketahui kondisi geografis berbukit dan terjal berada di lereng gunung dan lingkungan fisik rumah panggung dengan sarana sanitasi yang ada terutama air bersih sangat memprihatinkan, sumber airnya dari mata air yang terbuka/ tidak terlindung dan tidak terawat. Selain itu sebgaian besar masyarakat di desa tersebut masih menggunakan Jamban Cemplung (BAB ke kolam ikan)

\section{c. Hasil investigasi makanan}

Sampel makanan dan feses penderita sudah diamankan oleh pihak polsek Kalibunder dan sebagian sampel tersebut sudah dikirim ke laboratorium Kesehatan Daerah Probinsi Jawa Barat di Bandung pada hari Minggu 17 Nopember 2019. Sehingga pada saat Tim Kantor Kesehatan Pelabuhan mengadakan investigasi tidak berhasil melakukan pemeriksaan sampel tersebut. Dikarenakan sampel tersebut ternyata sudah dialihkan ke Polsek Tegalbuleud dimana akses ke polsek Kalibunder membutuhkan waktu 2.5 jam dari lokasi kejadian.

\section{d. Hasil Pemeriksaan Rapid Test}

- Pemeriksaan alat masak dan usap alat makan dilakukan pada katel, panci, piring dan gelas dengan menggunakan pemeriksaan Pro Clean untuk mengetahui residu protein dan pemeriksaan spotcheck plus untuk mengetahui residu glukosa didapatkan hasil sebagai berikut :

- Ketel menghasilkan warna ungu terang

- Panci menghasilkan warna ungu gelap
NOMOR 2 Juli 2020

p-ISSN : 1979-2344

e-ISSN : 2502-5414

- Piring menghasilkan warna hijau muda

- Gelas menghasilkan warna hijau muda Hasil pemeriksaan tersebut menunjukan bahwa alat masak dan alat makan tersebut mengandung residu glukosa dan residu protein

- Pemeriksaan air pada wadah derijen diketahui menggandung Alumunium sebesar 140ppm dan THH sebesar 182ppm serta tidak ditemukan merkuri.

- Pemeriksaan bahan makanan berupa bumbu bawang putih kemiri dan bumbu bawang merah cabai tidak diemukan kandungan Sianida dan arsenic.

\section{SIMPULAN}

a. Terjadi KLB keracunan Pangan pada tanggal 15 Nopember 2019, kasus terdistribusi di dua RT (RT 01 dan RT 03) di Desa Sirnamekar sebanyak 77 kasus

b. Attack rate KLB keracunan pangan terbesar pada jenis kelamin perempuan $(0.041 \%)$ dan kelompok umur 15->60 tahun $(0.029 \%)$

c. Case Fatality Rate pada KLB Keracunan Pangan sebesar 0.027

d. Gejala terbanyak pada kejadian KLB keracunan pangan ini adalah gejala mual $77.9 \%$ (60 orang) dan diare 67.5\% (52 orang)

e. Kurva epidemik pada kejadian KLB ini berbentuk common source dengan rentang masa inkubasi 30 menit sampai dengan 79.5 jam, dengan mean inkubasi 
JURNAL SEHAT MASADA

VOLUME XIV

12,51 jam. Berdasarkan masa inkubasi diperoleh informasi bahwa agent penyebab penyakit yang memungkinkan adalah bakteri E.colli

f. Berdasarkan jenis makanan yang dimakan, dicurigai bahwa makanan yang berisiko menyebabkan keracunan adalah bihun, dengan selisih attack rate sebesar 0.12

g. Hasil pemeriksaan rapid test pada alat masak didapatkan hasil positif mengandung residu glukosa dan residu protein

\section{REFERENSI}

WHO (2008), FoodBorne Disease Outbreaks : Guidelines for Investigation and Controls
NOMOR 2 Juli 2020

p-ISSN : 1979-2344

e-ISSN : 2502-5414

Undang - Undang Republik Indonesia No. 4 Tahun 1984, Wabah Penyakit Menular. Jakarta.

Peraturan Pemerintah No. 28 Tahun 2004, Keamanan, Mutu dan Gizi Pangan. Jakarta

Departemen Kesehatan RI, 2008, Petunjuk Teknis Surveilans Keracunan Pangan. Jakarta

Kementerian Kesehatan Republik Indonesia, Tahun 2011, Buku Pedoman Penyelidikan dan Penanggulangan Kejadian Luar Biasa Penyakit Menular dan Keracunan Pangan. Jakarta.

Chin, James, 2009, Manual Pemberantasan Penyakit Menular, Editor Penterjemah :I Nyoman Kandun. Edisi 17. Jakarta.

Sholah Imari, 2011, Investigasi KLB Keracunan Pangan. Jakarta. 